\title{
Determination of the Compressive Strength of Concrete Using Artificial Neural Network
}

\author{
Jose Manuel Palomino Ojeda, Stefano Rosario Bocanegra, Lenin Quiñones Huatangari* \\ Data Science Institute, National University of Jaen, Jaen, Peru \\ Received 10 April 2021; received in revised form 16 May 2021; accepted 17 May 2021 \\ DOI: https://doi.org/10.46604/ijeti.2021.7479
}

\begin{abstract}
The objective of the work is to estimate the compressive strength of concrete by means of the application of Artificial Neural Networks (ANNs). A database is created with design variables of mixtures of 175, 210, and 280 $\mathrm{kgf} / \mathrm{cm}^{2}$, which are collected from certified laboratories of soil mechanics and concrete of the city of Jaen. In addition, Weka software is used for the selection of the variables and Matlab software is used for the learning, training, and validation stages of ANNs. Five ANNs are proposed to estimate the compressive strength of concrete at $7^{\text {th }}, 14^{\text {th }}$, and $28^{\text {th }}$ day. The results show that the networks obtain the average error of $4.69 \%$ and are composed of an input layer with eleven neurons, two hidden layers with nine neurons each, and the compressive strength of concrete as the output. This method is effective and valid for estimating the compressive strength of concrete as a non-destructive alternative for quality control in the construction industry.
\end{abstract}

Keywords: concrete, ANN, artificial neural network, compressive strength

\section{Introduction}

The motivating factors of this study are as follows. First, in the city of Jaen, there are houses that have failed structurally due to low concrete strength, which can be predicted with the use of Neural Network (NN) model. Secondly, from the scientific point of view, the use of $\mathrm{NN}$ for the prediction of concrete strength based on nonlinear programming is relevant. Finally, from the functional point of view, by having a reliable mathematical model in real time to predict the compressive strength of concrete, state and/or private institutions can control the quality of concrete in various engineering works.

The increased interest and use of Artificial Neural Networks (ANNs) are due to their simplicity and effectiveness in developing a mathematical model [1]. ANNs have been used in various research fields, such as physics, medicine, geology, engineering, and specifically construction engineering [2-5]. In Tehran, ANNs are employed to predict the success of housing projects in the construction phase [6], Modified Neural Network Algorithm (MNNA) is used to optimize the gains of a controller, and a new mathematical modeling is introduced to promote the exploration form [7]. On the other hand, a NN predictive controller based on a genetic algorithm is designed for Automatic Voltage Regulator (AVR) [8].

The objective of the work is to estimate the strength of concrete through the application of ANNs for strengths of 175, 210, and $280 \mathrm{kgf} / \mathrm{cm}^{2}$. The difficulty and challenge of this work are the collection of information in different certified concrete laboratories in the city of Jaen, Peru. The study is organized as follows: Literature review is presented in section 2. Section 3 describes the materials and methods of the research. Section 4 provides the results. In section 5, the interpretation of the results is discussed. In section 6, the conclusions of this study and possible future work are presented.

* Corresponding author. E-mail address: lenin.quinones@unj.edu.pe 


\section{Literature Review}

Concrete is one of the most important materials used in the construction of buildings and other structures. This conglomerate is composed of fine and coarse aggregates, cement, and a controlled amount of water [9], as well as additions that improve its properties [10]. These characteristics act on the strength of concrete directly [11]. Thus, mix designs are made based on these properties for their dosage, but these not only influence the strength of concrete, but also influence the characteristics of environment, such as the temperature [12-13] of environment and the origin of materials.

The development of infrastructure in the city of Jaen in Peru is constant, and the construction is expanding around it, being mainly single-family and multifamily dwellings [14]. Given this situation, the need for quality control, supervision, and professional advice arises since most of the constructions are informal [15]. However, the preparation, processing, and curing of concrete is not carried out according to the Peruvian Technical Standard, resulting in concrete that does not meet the strength specified on site [16] and being a danger to the structural stability of the houses in the event of seismic events [17].

The compressive strength of concrete is the most widely used parameter to define the characteristics of concrete in hardened state, and for its evaluation, concrete briquettes are made at the time of mixing [11]. The influence of the proportions of the mixture, characteristics of its ingredients, water/cement ratio are indispensable for the design of mixtures which provide us with the dosage of ingredients for the preparation of concrete. In addition, procedures of mixing, transport, placement, vibration, and the circumstances of curing have incidence in the compressive strength of concrete. Conventional procedures for the processing and curing of concrete by means of standardized tests allow determining the design strength when the concrete reaches the age of $28^{\text {th }}$ day [10]. In order to predict the compressive strength of concrete by non-destructive methods, information on the design of the mixes with their respective compression tests is necessary. From this, this variable is obtained without the need to perform the axial compression test. In addition, there are traditional methods based on statistical developments that use linear and non-linear equations, where the major dependence between the variables that influence the strength is non-linear, and generally is not considered [18].

ANN is a computational model whose architecture mimics the behavioral relationships of the brain. ANN demonstrates an abstract and simplified view of the biological neuron consisting of a limited number of interconnected elements [19]. Its layers have an activation function, whose output is represented by Eq. (1).

$$
Y_{N X 1}=f\left(W_{N X M} X_{M, 1}+b_{N, 1}\right)
$$

where $Y$ is a vector containing the output of each of the $N$ neurons in each given layer, $N$ is the matrix containing the synaptic weights for each of the $M$ outputs for all $N$ neurons, $X$ is the vector containing the inputs, $b$ is the vector containing the biases, $f$ is the nonlinear activation function, and $Z$ is the expression contained within the parenthesis of Eq. (1). The sigmoid function expressed in Eq. (2) is often used [1].

$$
f(Z)=\frac{1}{1+e^{-z}}
$$

The multilayer perceptron ANN has an input layer where the information from the outside (input data) is introduced and distributed to the internal or hidden layers, which are responsible for performing the necessary calculations to achieve an output, and the output layer finally shows the results obtained by the network (output data) [21]. The learning stage of ANN extracted from the input data is stored among different neurons that compose the network, which allows ANN to be used on unknown data [22]. Moreover, it is an effective method to estimate concrete strength. Lizarazo and Gómez [19] investigated the development of ANN models to predict compressive strength by unit weight and ultrasonic pulse velocity using 41 different concrete mixtures, and obtained an average error of $9.3 \%$ in the different models. On the other hand, Acuña et al. [23] 
used 500 concrete briquettes manufactured with different types and amounts of cement, sand, stone, water, additives, and microsilica. They used different curing periods, where the NN composed of two hidden layers predicted $90 \%$ of the totality of the specimens considered and the results obtained during the network development process showed a coefficient of determination $\left(\mathrm{R}^{2}\right)$ of 0.83 . Octavio et al. [24] used ANNs to estimate the fresh and hardened properties of concrete reinforced with metallic fibers. For this purpose, they elaborated and trained NNs with the Levenberg-Marquardt Algorithms (LMA) and Scale Conjugate Gradient (SCG) using Matlab software. They used a database of mechanical and slump tests of Abrams cones. Each record is a vector of information with data on raw material dosages and qualitative characteristics, such as cement type, aggregate origin, lithological profile of the coarse aggregate, and type of metallic fiber, modeling a two-layer hidden network with the LMA learning method and obtaining a correlation coefficient $(\mathrm{R})$ of 0.98 in the estimation of compressive strength.

Therefore, the use of NNs to estimate the compressive strength of concrete can diagnose the behavior of the material to be used on site, being a non-destructive methodology that gives support to evaluate the concrete without damaging the structure. This research focuses on the strength property. However, in the use of these methodologies, it is essential to know their limitations, and in the case of NN, its accuracy is obtained through a validation process by means of statistical tests.

The contributions of the research are represented in the following points:

(1) This work employs ANNs to determine the compressive strength of concrete instead of employing conventional destructive methods, such as the use of hydraulic press.

(2) The input variables of the ANN are those that most influence the compressive strength of concrete and have been obtained from the database collected from mix designs and laboratory tests by means of a statistician. Some of them are different from those used in other studies [19-20, 23-24] due to the characteristics of the origin of the aggregates in the study area.

\section{Materials and Methods}

\subsection{Type and design of research}

The type of research is applied since the researchers seek the production of knowledge (NN model). Likewise, the research design is experimental since the independent variable (ANNs) is manipulated to appreciate the effects on the dependent variable (compressive strength) in the production of concrete.

\subsection{Procedure for using ANNs}

\subsubsection{Mix design}

The mix design is based on the method proposed by the American Concrete Institute system [25], which is used for concrete batching and is carried out according to the expected strength. Also, the mix design is based on laboratory tests to calculate the optimum batching.

\subsubsection{Database for ANN training}

The database for ANN training is created from the information obtained from soil mechanics and concrete laboratories in the city of Jaen, which is certified by National Institute of Quality (INACAL). Also, it is related to concrete studies, which are extracted from the institutional repository of the National University of Jaen, during the years 2015-2020. Table 1 presents the compressive strength tests with their characteristics and mix design parameters.

The database is used for teaching and training ANNs, and consists of 675 records that constitute the complete information vectors of the database matrix for the variables involved. The compressive strength is based on the standardized test methodology NTP 339.034, and the cylindrical specimens at $7^{\text {th }}, 14^{\text {th }}$, and $28^{\text {th }}$ day are subjected to compressive stresses. 
Table 1 Mix design parameters and additional characteristics

\begin{tabular}{|c|c|c|c|c|c|}
\hline Group & Concept & Variable & Unit & Symbol & ANN representation \\
\hline \multirow{6}{*}{ Cement } & \multirow{6}{*}{ Cement } & Quantity & $\mathrm{Kg}$ & $\mathrm{CA}-\mathrm{C}$ & Real numeric \\
\hline & & Specific weight & $\mathrm{Kg} / \mathrm{cm} 3$ & PE-C & Real numeric \\
\hline & & Inca type I & - & CE-IT1 & {$[1000]$} \\
\hline & & $\begin{array}{l}\text { Pacasmayo Fortimax } \\
\text { anti-saltpeter type MS }\end{array}$ & - & CE-PFA & {$[0100]$} \\
\hline & & Pacasmayo type I & - & CE-PCT1 & {$[0010]$} \\
\hline & & Pacasmayo type ICO & - & CE-PCICO & {$[0001]$} \\
\hline Total water & Water & Quantity & $\mathrm{Kg}$ & W & Real numeric \\
\hline \multirow{18}{*}{ Aggregates } & \multirow{9}{*}{ Sand } & Quantity & $\mathrm{Kg}$ & $\mathrm{S}$ & Real numeric \\
\hline & & River bed & - & CF-R & {$[10]$} \\
\hline & & Quarry & - & CF-C & [01] \\
\hline & & Humidity & $\%$ & $\mathrm{H}-\mathrm{S}$ & Real numeric \\
\hline & & Absorption AF & $\%$ & ABS-S & Real numeric \\
\hline & & Specific weight & $\mathrm{Kg} / \mathrm{cm} 3$ & PE-S & Real numeric \\
\hline & & Fineness modulus & - & MF & Real numeric \\
\hline & & Unit loose weight & $\mathrm{Kg} / \mathrm{cm} 3$ & PUS-S & Real numeric \\
\hline & & Unit weight varillado & $\mathrm{Kg} / \mathrm{cm} 3$ & PUV-S & Real numeric \\
\hline & \multirow{9}{*}{ Gravel } & Quantity & $\mathrm{Kg}$ & $\mathrm{G}$ & Real numeric \\
\hline & & River bed & - & CG-R & [10] \\
\hline & & Quarry & - & CG-C & [01] \\
\hline & & Humidity & $\%$ & H-G & Real numeric \\
\hline & & Maximum nominal size & $\mathrm{m}$ & G-TMN & Real numeric \\
\hline & & Absorption AG & $\%$ & ABS-G & Real numeric \\
\hline & & Specific weight & $\mathrm{Kg} / \mathrm{cm} 3$ & PE-G & Real numeric \\
\hline & & Unit loose weight & $\mathrm{Kg} / \mathrm{cm} 3$ & PUS-G & Real numeric \\
\hline & & Unit weight varillado & $\mathrm{Kg} / \mathrm{cm} 3$ & PUV-G & Real numeric \\
\hline Trapped air & Air & Quantity & $\%$ & AT & Real numeric \\
\hline \multirow[t]{2}{*}{ Characteristics } & $\begin{array}{c}\text { Design } \\
\text { strength }\end{array}$ & f'c-design & $\mathrm{Kg} / \mathrm{cm} 2$ & R-D & Real numeric \\
\hline & Age in days & Age & Día & D-A & Real numeric \\
\hline \multirow{3}{*}{ Properties } & Proportion & Water-cement ratio & - & $\mathrm{A}-\mathrm{C}$ & Real numeric \\
\hline & Workability & Settlement & - & AS & Real numeric \\
\hline & $\begin{array}{l}\text { Compressive } \\
\text { strength }\end{array}$ & Strength & $\mathrm{Kg} / \mathrm{cm} 2$ & $\mathrm{f}^{\prime} \mathrm{c}$ & Real numeric \\
\hline
\end{tabular}

Table 2 Relevant variables for each training set

\begin{tabular}{|c|c|c|c|}
\hline Variable & Unit & Symbol & $\mathrm{R}$ \\
\hline f'c-design & $\mathrm{Kg} / \mathrm{cm}^{2}$ & $\mathrm{R}-\mathrm{D}$ & 0.48153 \\
\hline Quantity-cement & $\mathrm{Kg}$ & $\mathrm{CA}-\mathrm{C}$ & 0.34451 \\
\hline Briquette age & $\mathrm{h}$ & $\mathrm{D}-\mathrm{A}$ & 0.34401 \\
\hline Specific weight-cement & $\mathrm{Kg} / \mathrm{cm}^{3}$ & $\mathrm{PE}-\mathrm{C}$ & 0.20493 \\
\hline Cement type & - & $\mathrm{CE}$ & 0.17068 \\
\hline Settlement & - & $\mathrm{AS}$ & 0.15686 \\
\hline Specific weight-coarse aggregate & $\mathrm{Kg} / \mathrm{cm}^{3}$ & $\mathrm{PE}-\mathrm{G}$ & 0.10918 \\
\hline Quarry-coarse aggregate & - & $\mathrm{CG}$ & 0.10892 \\
\hline Quarry-fine aggregate & - & $\mathrm{CF}$ & 0.09723 \\
\hline Quantity-fine aggregate & $\mathrm{Kg}$ & $\mathrm{S}$ & -0.11110 \\
\hline A/C-design ratio & - & $\mathrm{A}-\mathrm{C}$ & -0.36588 \\
\hline
\end{tabular}

For the selection of input variables and the conformation of information vectors (records), the conditions of dependence of the concrete compressive strength are taken into account. The 26 variables collected in the database are grouped as follows: cement, total water, aggregates, entrapped air, characteristics, and properties. The latter contains the output variable in the third item, compressive strength. Likewise, the variables that most influence the compressive strength of the concrete are selected. 
For this purpose, the correlation coefficient $(\mathrm{R})$ is used, which shows the linear relationship of the input variables with the output variable, whose values have greater influence when they are close to -1 and 1 . The calculation of this coefficient is performed in the Weka software. After obtaining these values, eleven variables with a coefficient lower than -0.100 and higher than 0.090 are chosen and considered for the input layer of NN, as shown in Table 2.

\subsubsection{Database for ANN validation}

A database is constructed for the validation process of ANNs considering eleven variables of major incidence in concrete compression (Table 3). This source is obtained experimentally using 90 concrete briquettes, manufactured with different types and amounts of cement, sand, stone, and water in which NTP 339.033 [26] and ASTM C 39/C 39M [27] are followed. As for the axial compression tests, they have been performed according to NTP 339.034 [28] and ASTM C 192/C 192M [29] with curing periods of $7^{\text {th }}, 14^{\text {th }}$, and $28^{\text {th }}$ day.

Table 3 Input variables for validation of results

\begin{tabular}{|c|c|c|c|c|c|c|c|c|c|c|}
\hline $\begin{array}{c}\text { Quantity- } \\
\text { cement } \\
\text { (Kg) }\end{array}$ & $\begin{array}{c}\text { Specific } \\
\text { weight- } \\
\text { cement }\end{array}$ & $\begin{array}{c}\text { Cement } \\
\text { type }\end{array}$ & $\begin{array}{c}\text { Quantity-fine } \\
\text { aggregate }\end{array}$ & $\begin{array}{c}\text { Quarry-fine } \\
\text { aggregate }\end{array}$ & $\begin{array}{c}\text { Quarry- } \\
\text { coarse } \\
\text { aggregate }\end{array}$ & $\begin{array}{c}\text { Specific weight- } \\
\text { coarse aggregate } \\
(\text { gr/cm })^{3}\end{array}$ & Settlement & $\begin{array}{c}\text { A/C- } \\
\text { design } \\
\text { ratio }\end{array}$ & $\begin{array}{c}\text { f'c-design } \\
\text { Briquette } \\
\text { age } \\
\text { (days) }\end{array}$ \\
\hline 342.86 & 3.1 & 10 & 910.99 & 1 & 1 & 2.72 & 1 & 0.63 & 175 & 7 \\
\hline 342.86 & 3.1 & 10 & 910.99 & 1 & 1 & 2.72 & 1 & 0.63 & 175 & 14 \\
\hline 342.86 & 3.1 & 10 & 910.99 & 1 & 1 & 2.72 & 1 & 0.63 & 175 & 28 \\
\hline 385.71 & 3.1 & 10 & 876.67 & 1 & 1 & 2.72 & 1 & 0.56 & 210 & 7 \\
\hline 385.71 & 3.1 & 10 & 876.67 & 1 & 1 & 2.72 & 1 & 0.56 & 210 & 14 \\
\hline 385.71 & 3.1 & 10 & 876.67 & 1 & 1 & 2.72 & 1 & 0.56 & 210 & 28 \\
\hline 459.57 & 3.1 & 10 & 813.29 & 1 & 1 & 2.72 & 1 & 0.47 & 280 & 7 \\
\hline 459.57 & 3.1 & 10 & 813.29 & 1 & 1 & 2.72 & 1 & 0.47 & 280 & 14 \\
\hline 459.57 & 3.1 & 10 & 813.29 & 1 & 1 & 2.72 & 1 & 0.47 & 280 & 28 \\
\hline
\end{tabular}

To determine the compressive strength, 90 cylindrical concrete specimens are tested at $7^{\text {th }}, 14^{\text {th }}, 28^{\text {th }}$ day of production for each of the mix designs, namely $175 \mathrm{kgf} / \mathrm{cm}^{2}, 210 \mathrm{kgf} / \mathrm{cm}^{2}$, and $280 \mathrm{kgf} / \mathrm{cm}^{2}$. Table 4 shows the averages obtained from the tests performed.

Table 4 Average compressive strength of concrete ( $\mathrm{f}^{\prime} \mathrm{c}=175,210$, and $280 \mathrm{kgf} / \mathrm{cm}^{2}$ )

\begin{tabular}{|c|c|c|c|}
\hline f'c-design $\left(\mathrm{Kg} / \mathrm{cm}^{2}\right)$ & Age (days) & f'c average $(\%)$ & f'c average $\left(\mathrm{Kg} / \mathrm{cm}^{2}\right)$ \\
\hline \multirow{3}{*}{175} & 7 & 78.79 & 137.88 \\
\cline { 2 - 4 } & 14 & 103.56 & 181.22 \\
\cline { 2 - 4 } & 28 & 121.04 & 211.82 \\
\hline \multirow{3}{*}{210} & 7 & 74.64 & 156.75 \\
\cline { 2 - 4 } & 14 & 101.33 & 212.78 \\
\cline { 2 - 4 } & 28 & 118.29 & 248.40 \\
\hline \multirow{3}{*}{280} & 7 & 78.60 & 220.08 \\
\cline { 2 - 4 } & 14 & 102.59 & 287.26 \\
\cline { 2 - 4 } & 28 & 117.95 & 330.25 \\
\hline
\end{tabular}

\subsubsection{Development, training, and validation of ANNS}

For data preparation, the gradient descent or conjugate gradient method with SCG scaling is chosen as the training method. Once the main ANN program is executed, LMA is chosen as the training method, according to the work of Gonzáles et al. [30]. To determine the number of corresponding neurons, the program is run on eleven ANN architectures, so a two-hidden-layer architecture, each with nine neurons, is selected as it has a higher correlation coefficient, as shown in Table 5. The ANN architecture described as [k1 k2] refers to the number of hidden layers, respectively.

Five NNs are trained with a multilayer typology consisting of an input layer, a first hidden layer with nine neurons, a second hidden layer with nine neurons, and an output layer in each NN, corresponding to the concrete compressive strength. The input and output variables (neurons) of each NN developed and trained are shown in Table 6. 
Table 5 Selection of the number of neurons in the two hidden layers using the correlation factor

\begin{tabular}{|c|c|}
\hline $\begin{array}{c}\text { ANN architecture } \\
{[\mathrm{k} 1 \mathrm{k} 2]}\end{array}$ & $\mathrm{R}^{2}$ \\
\hline$[0909]$ & 0.86 \\
\hline$[1015]$ & 0.83 \\
\hline$[150]$ & 0.82 \\
\hline$[250]$ & 0.84 \\
\hline$[250]$ & 0.85 \\
\hline$[3005]$ & 0.83 \\
\hline$[3509]$ & 0.85 \\
\hline$[4005]$ & 0.84 \\
\hline$[4040]$ & 0.82 \\
\hline$[5040]$ & 0.85 \\
\hline$[5050]$ & 0.85 \\
\hline
\end{tabular}

Table 6 Conformation of ANNs and input variables for compressive strength estimation

\begin{tabular}{|c|c|c|}
\hline Neural network & Entries & Output \\
\hline ANN_01 & CA-C, PE-C, S, CF, CG, PE-G, A-C, R-D, D-A & f'c \\
\hline ANN_02 & CA-C, CE, S, CF, CG, PE-G, AS, A-C, R-D, D-A & f'c \\
\hline ANN_03 & CA-C, PE-C, S, CF, CG, PE-G, AS, A-C, R-D, D-A & f'c \\
\hline ANN_04 & CA-C, PE-C, CE, S, CF, CG, PE-G, A-C, R-D, D-A & f'c \\
\hline ANN_05 & CF, S, A-C, CG, PE-G, AS, CE, PE-C, D-A, CA-C, R-D & f'c \\
\hline
\end{tabular}

The training, validation, and testing phases are performed with the Matlab NN tool, with which several configurations are designed for the $5 \mathrm{NNs}$ consisting of different learning algorithms and parameter variation. In the validation phase, each network performs the processing of the database considered to validate the models. Considering the relationships learned in the training process, the synaptic weights are saved and stored in vector form. The compressive strength of the test briquettes is the output of the network. Distinguishing this prediction with the actual value will provide evidence of the predictive capability of the model.

\subsubsection{ANN performance evaluation}

The following techniques are used: Root Mean Square Error (RMSE) (Eq. (3)), Sum of Squares Error (SSE) (Eq. (4)), coefficient of determination $\left(\mathrm{R}^{2}\right)$ (Eq. (5)), and mean error according to the work of Goyal et al. [31]. The error found for each simulated data is established by Eq. (6).

$$
\begin{aligned}
& R M S E=\sqrt{\sum_{t=1}^{T} \frac{\left(Y_{t}-P_{t}\right)^{2}}{T}} \\
& S S E=\sum_{t=1}^{T}\left(P_{t}-\bar{P}_{t}\right)^{2} \\
& R^{2}=1-\frac{\sum_{t=1}^{T}\left(Y_{t}-P_{t}\right)^{2}}{\sum_{t=1}^{T}\left(Y_{t}-\bar{P}_{t}\right)^{2}}
\end{aligned}
$$

where $Y_{t}$ is the desired output, $P_{t}$ is the obtained output, $\bar{P}_{t}$ is the average of the obtained outputs, and $T$ is the number of records taken in each phase (learning and validation). 


$$
\text { Error }[\%]=\left|\frac{R_{\text {real }}-R_{\text {simul }}}{R_{\text {real }}}\right| \times 100
$$

where $R_{\text {real }}$ and $R_{\text {simul }}$ are the real and simulated resistance values, respectively.

\subsection{Data analysis}

The collected data are stored in .csv format in Excel software, then descriptive statistics are used to evaluate the behavior of the variables in the determination of the compressive strength of concrete. In addition, Matlab R2017a software is used for the design, training, and validation of the proposed ANNs.

\section{Results}

After designing the five proposed NNs configured with different input variables, the compressive strength of concrete at different ages are obtained (Table 7). The structure of ANN_01, ANN_03, and ANN_05 is shown in Figs. 1-3; ANN_02 and ANN_04 networks are discarded for having a higher average error in the training process. ANN_01, ANN_03, and ANN_05 are evaluated considering the experimentally obtained database (database for validation) in terms of the coefficient of determination $\left(\mathrm{R}^{2}\right)$, as shown in Table 8 and Figs. 4-6.

Table 1 Estimation of the compressive strength of concrete using the proposed models

\begin{tabular}{|c|c|c|c|c|c|c|}
\hline f'c-design $\left(\mathrm{kgf} / \mathrm{cm}^{2}\right)$ & Age (days) & ANN_01 & ANN_02 & ANN_03 & ANN_04 & ANN_05 \\
\hline \multirow{3}{*}{175} & 7 & 144.00 & 134.41 & 166.78 & 146.11 & 133.91 \\
\cline { 2 - 7 } & 14 & 183.23 & 202.33 & 181.47 & 165.1 & 170.06 \\
\cline { 2 - 7 } & 28 & 221.76 & 207.18 & 212.58 & 180.24 & 201.89 \\
\hline \multirow{3}{*}{210} & 7 & 142.27 & 132.23 & 157.75 & 174.05 & 152.39 \\
\cline { 2 - 7 } & 14 & 196.11 & 179.16 & 187.49 & 209.41 & 207.54 \\
\cline { 2 - 7 } & 28 & 266.24 & 271.5 & 229.55 & 257.53 & 248.73 \\
\hline \multirow{3}{*}{280} & 7 & 238.72 & 223.88 & 233.3 & 260.12 & 190.15 \\
\cline { 2 - 7 } & 14 & 280.68 & 231.7 & 297.46 & 292.94 & 264.99 \\
\cline { 2 - 7 } & 28 & 341.60 & 345.2 & 333.5 & 324.03 & 335.94 \\
\hline
\end{tabular}

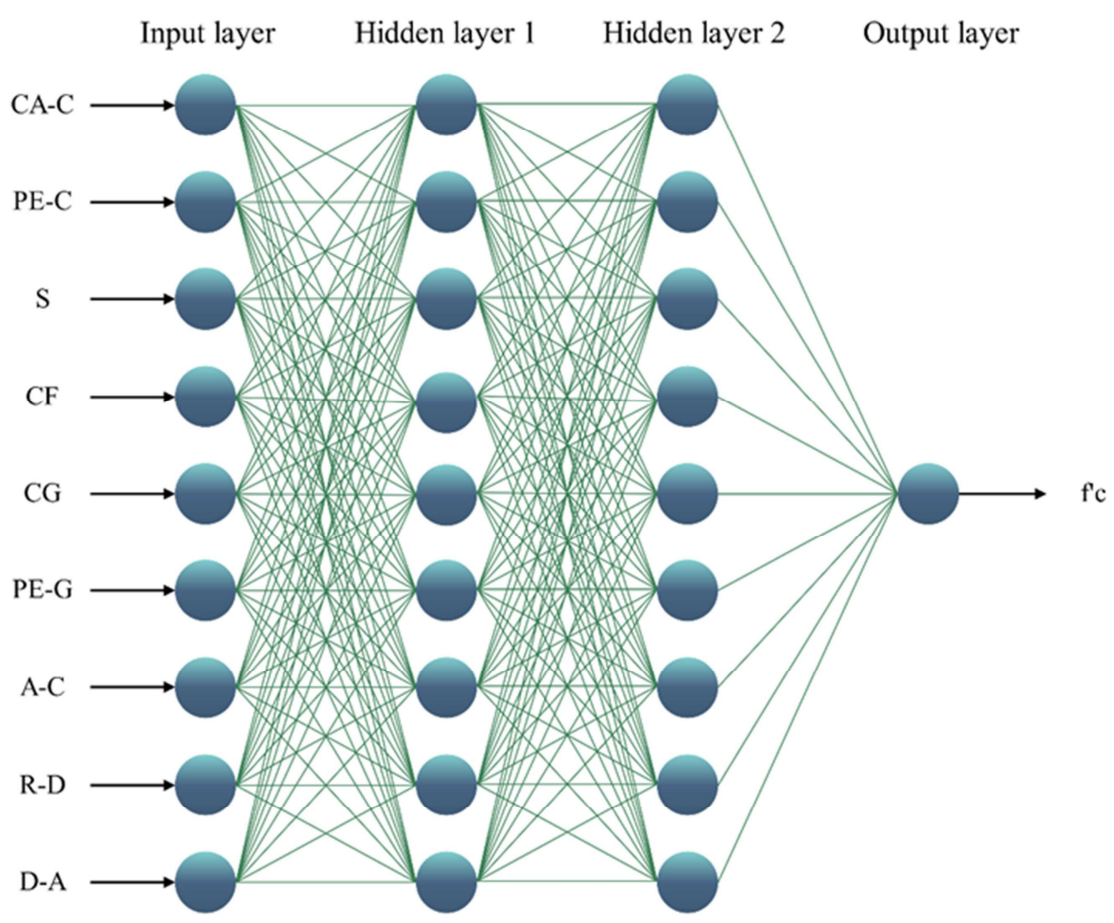

Fig. 1 The predicted and actual values of ANN_01 


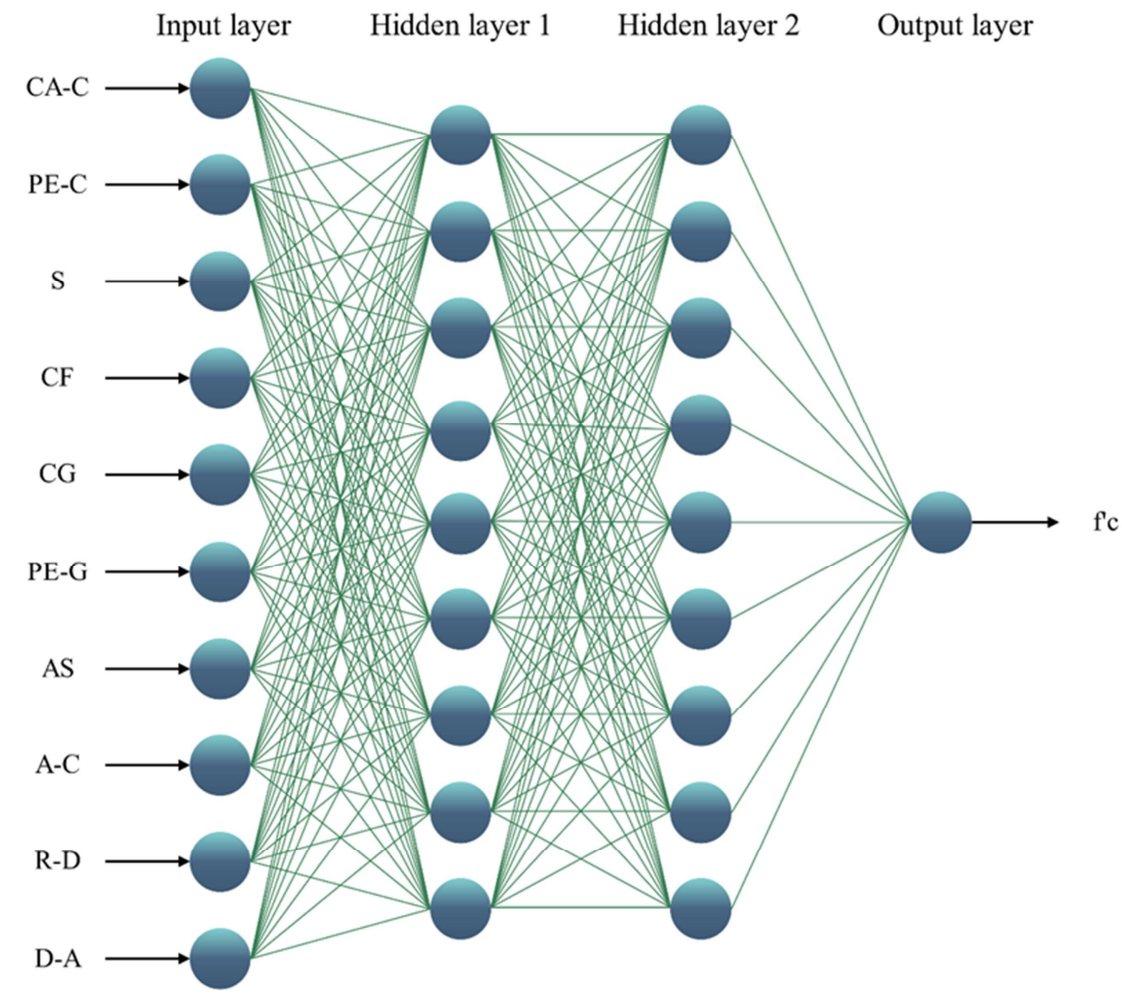

Fig. 2 Structure of ANN_03

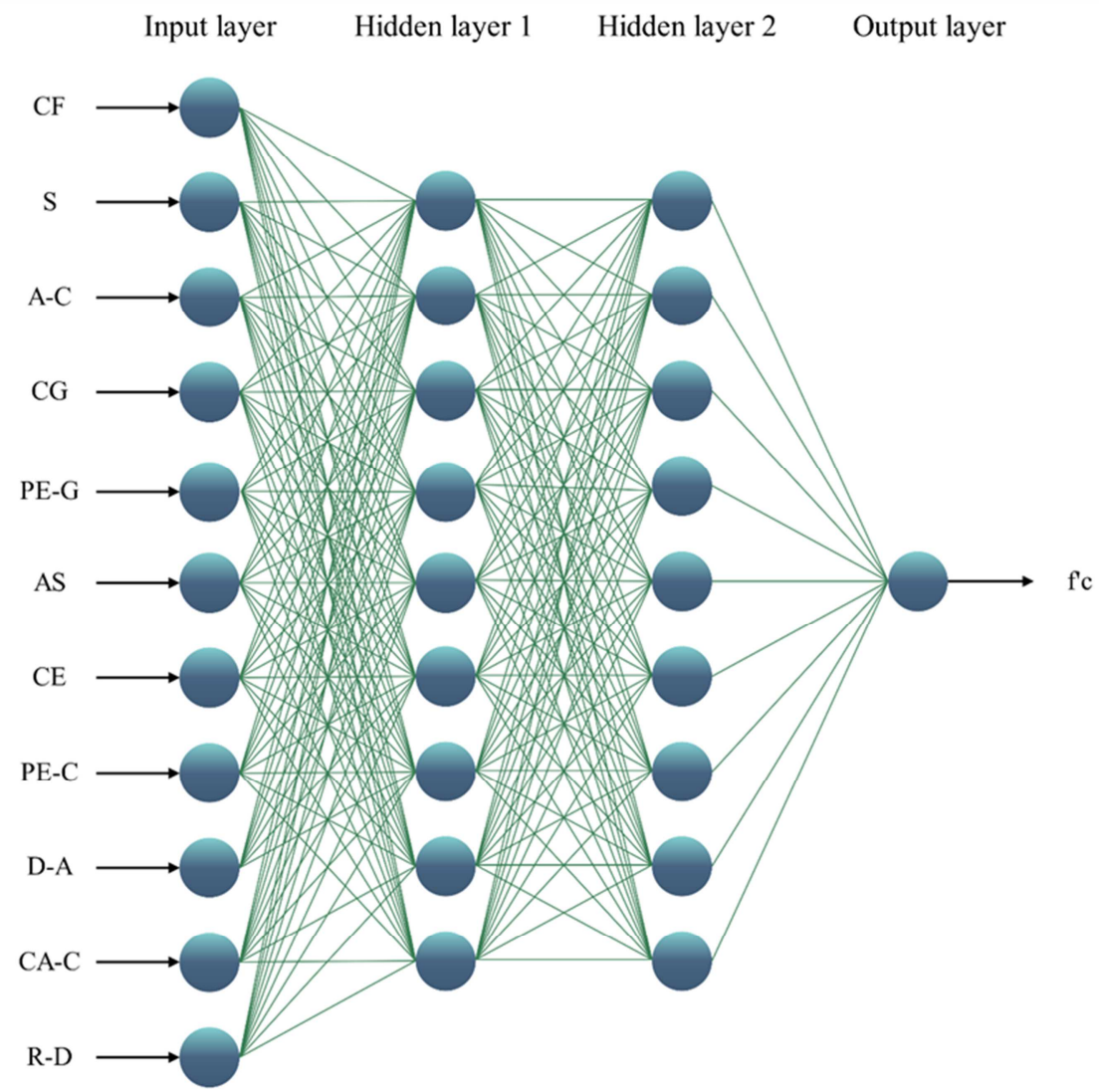

Fig. 3 Structure of ANN_05

Table 8 Performance evaluation of ANN_01, ANN_03, and ANN_05

\begin{tabular}{|c|c|c|c|}
\hline ANN & Average error & RMSE & $\mathrm{R}^{2}$ \\
\hline ANN_01 & $5.41 \%$ & 11.91 & 0.96 \\
\hline ANN_03 & $5.79 \%$ & 14.89 & 0.93 \\
\hline ANN_05 & $4.69 \%$ & 10.49 & 0.97 \\
\hline
\end{tabular}




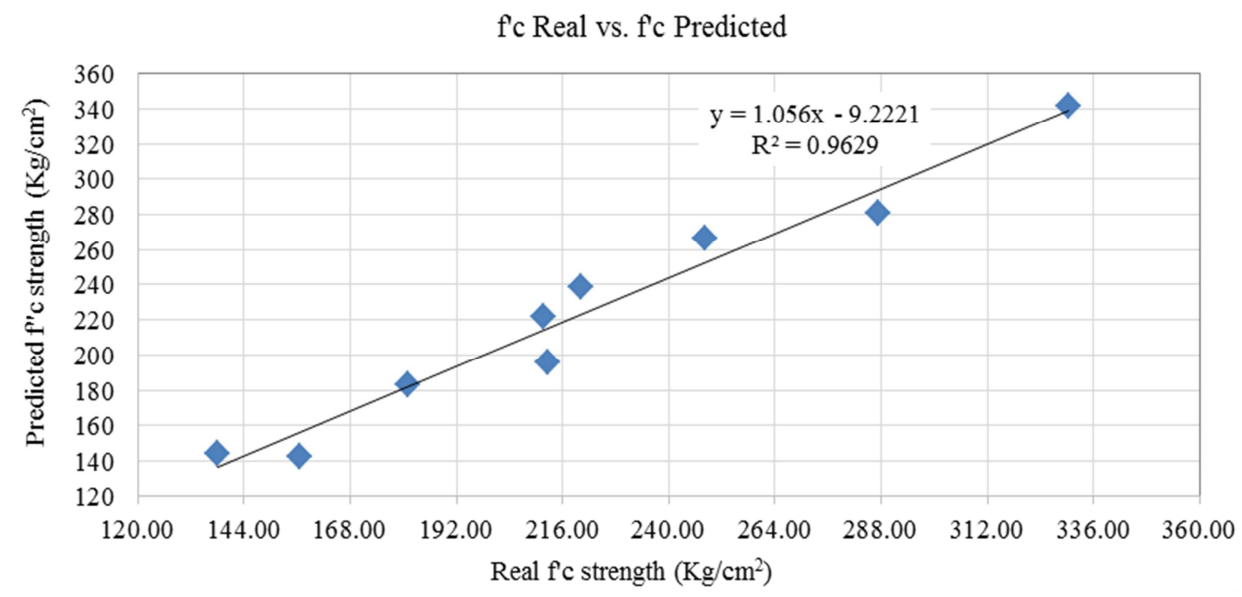

Fig. 4 The predicted and actual values of ANN_01

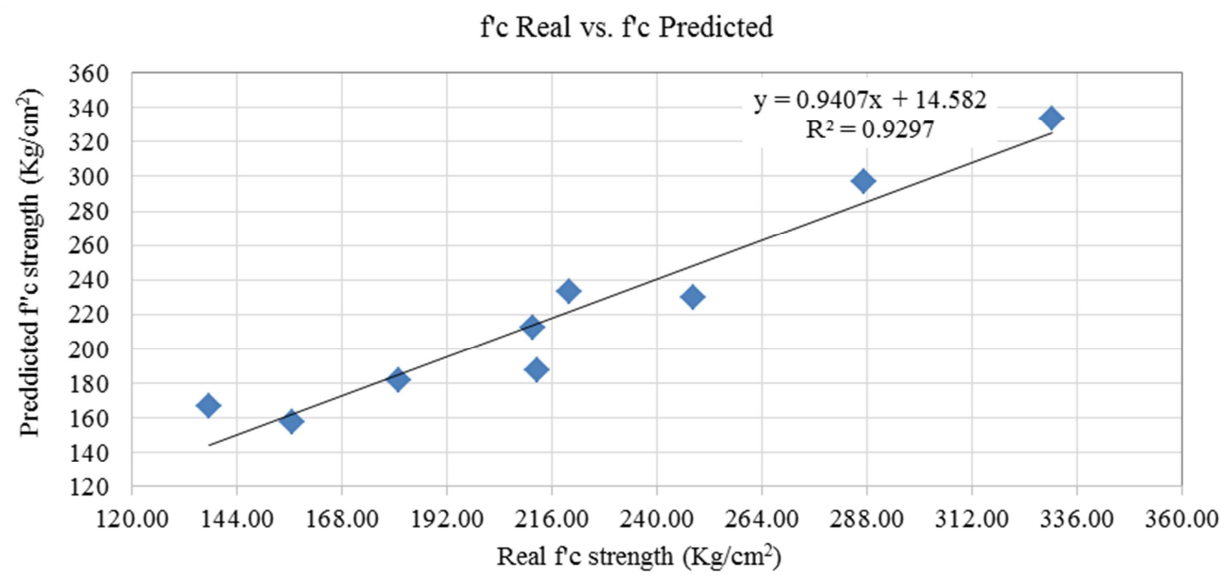

Fig. 5 The predicted and actual values of ANN_03

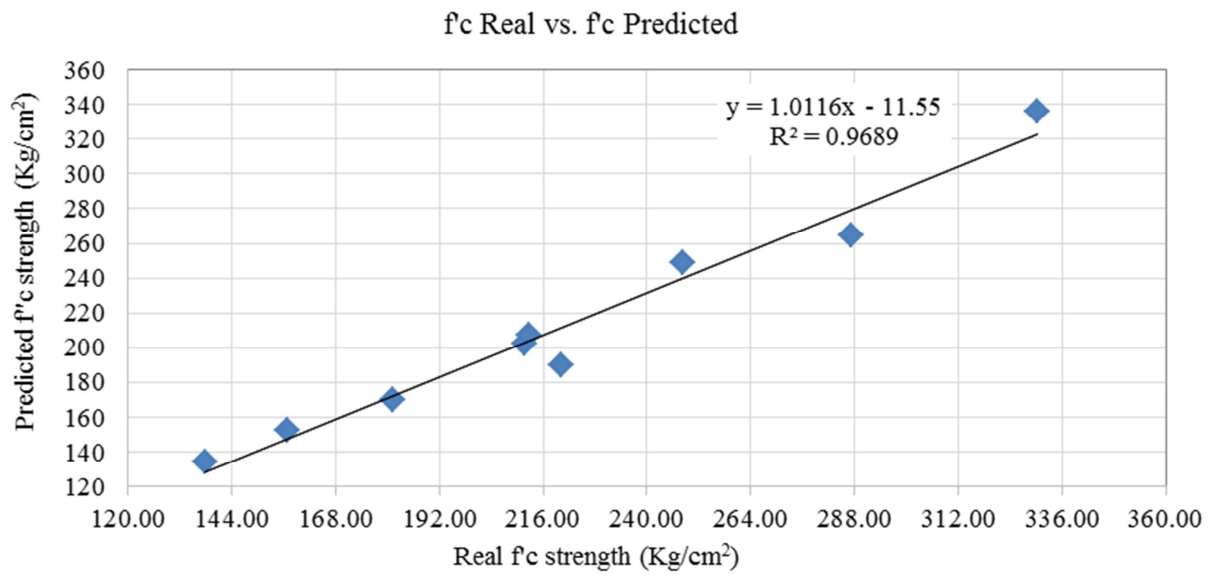

Fig. 6 The predicted and actual values of ANN_05

\section{Discussion}

The research is carried out in the province of Jaen, Peru because most of the constructions present structural failures due to the low strength of the concrete caused by the lack of quality control and professional advice. However, it can be taken as a reference for future studies in other provinces or regions of Peru, whose objective is to estimate the strength of concrete with construction aggregates from the study area.

The database for the construction of the model consists of 675 records and 26 variables, which represents physical and chemical characteristics of the materials used for concrete production, as well as the information used in the mix design. In the input layer of the proposed NNs, nine to eleven variables that have the greatest impact on the compressive strength of concrete 
are considered, namely: f'c-design, quantity-cement, briquette age, specific gravity-cement, type of cement, slump, specific gravity-coarse aggregate, quarry-coarse aggregate, A/C-design ratio, quantity-fine aggregate, and quarry-fine aggregate, collected from the soil mechanics and concrete thesis laboratories of the city of Jaen. It should be mentioned that the work of Tello [32] used ANNs in the modeling of the compressive strength test of construction concrete for the city of Cajamarca according to the international standard ASTM C 39/C 39M, differing from the present research, which also uses Peruvian standards.

The variables considered in the proposed network are similar to the variables used by Acuña et al. [23]: identification of the samples, area of the concrete briquettes, additive, \% microsilica, A/C ratio, amount of cement, and amount of sand, as well as the variables used by Gonzáles et al. [30] and Salcedo et al. [33]: amount of cement, type of cement, additions, amount of water, reducing agent, amount of sand, amount of gravel, origin of the materials, and air included. The same occurs with Gonzáles et al. [30] where there is similarity with the variables quantity-cement, type of cement, quantity-fine aggregate, quarry-fine aggregate, and quarry-coarse aggregate. This is due to the fact that the variables that influence concrete compression in each zone differ, for example, the characteristics of the aggregates, both fine and coarse. The A/C-design ratio, the amount of cement, and the amount of fine aggregates are the most influential variables in the compressive strength of concrete.

Five NNs are designed and trained, from which those with the lowest mean square error are selected with respect to the performance evaluation of the compressive strength estimation, and the graphical behavior between the actual and estimated values of the proposed neural model is consistent with the behavior presented in the neural model proposed in [20, 23, 30, 32]. The results obtained in the performance indicator show that the coefficients of determination are $R^{2}=0.941, R^{2}=0.92, R^{2}=$ 0.83 , and $\mathrm{R}^{2}=0.978$, respectively. When they are compared with the coefficients of determination obtained in the research, $\mathrm{R}^{2}$ $=0.968$ is acceptable since this value is higher than that obtained in $[20,23,30,32]$ and is within the range to estimate with high accuracy the compressive strength of concrete with a significance of $4 \%$. The coefficient of determination takes values between 0 and 1, as shown in Eq. (5). Therefore, if the value obtained is close to one, it implies that the fit of the model to calculate the compressive strength of concrete will be better.

\section{Conclusions}

In this work, the compressive strength of concrete was determined for designs of 175, 210, and $280 \mathrm{kgf} / \mathrm{cm}^{2}$ using ANNs. Five ANNs were proposed, with feedforward typology, backpropagation learning, and multilayer architecture. ANN_05 was the closest to the real results, which was composed of an input layer with eleven neurons (quarry-fine aggregate, quantity-fine aggregate, A/C-design ratio, quarry-coarse aggregate, specific weight-cement, settlement, cement type, specific weight-cement, briquette age, quantity-cement, and f'c-design), two hidden layers with nine neurons each, and the concrete compressive strength as the output. ANN_05 calculated the concrete compressive strength with an error of 4.69\%, and when it is evaluated with the error performance indicator, the coefficient of determination $\left(\mathrm{R}^{2}\right)$ of 0.968 shows a significance of $3 \%$.

For future work, it is proposed to use various mathematical modeling techniques, data mining, or optimization techniques, such as the one proposed by Elsisi [34], to estimate the compressive strength of concrete with greater reliability. These results would allow the creation of software become alternatives to the quality control of concrete in the construction industry.

\section{Conflicts of Interest}

The authors declare no conflict of interest. 


\section{References}

[1] M. H. Nyarko, E. K. Nyarko, N. Ademović, I. Miličević, and T. K. Šipoš, "Modelling the Influence of Waste Rubber on Compressive Strength of Concrete by Artificial Neural Networks," Materials, vol. 12, no. 4, 561, February 2019.

[2] X. Zhang, Y. Zhang, B. Qian, X. Liu, X. Li, X. Wang, et al., "Classifying Breast Cancer Histopathological Images Using a Robust Artificial Neural Network Architecture," International Work-Conference on Bioinformatics and Biomedical Engineering, vol. 11465, pp. 204-215, May 2019.

[3] B. S. Rem, N. Käming, M. Tarnowski, L. Asteria, N. Fläschner, C. Becker, et al., "Identifying Quantum Phase Transitions Using Artificial Neural Networks on Experimental Data,” Nature Physics, vol. 15, pp. 917-920, July 2019.

[4] A. G. Pala, A. Hola, and L. Sadowski, "A Non-Destructive Method of the Evaluation of the Moisture in Saline Brick Walls Using Artificial Neural Networks,” Archives of Civil and Mechanical Engineering, vol. 18, no. 4, pp. 1729-1742, September 2018.

[5] L. Sadowski, M. P. Mielnik, T. Widziszowski, A. Gardynik, and S. Mackiewicz, "Hybrid Ultrasonic-Neural Prediction of the Compressive Strength of Environmentally Friendly Concrete Screeds with High Volume of Waste Quartz Mineral Dust," Journal of Cleaner Production, vol. 212, pp. 727-740, March 2019.

[6] H. Youneszadeh, A. Ardeshir, and M. H. Sebt, "Predicting Project Success in Residential Building Projects (RBPs) Using Artificial Neural Networks (ANNs)," Civil Engineering Journal, vol. 6, no. 11, pp. 2203-2219, October 2020.

[7] M. Elsisi, K. Mahmoud, M. Lehtonen, and M. Darwish, “An Improved Neural Network Algorithm to Efficiently Track Various Trajectories of Robot Manipulator Arms,” IEEE Access, vol. 9, pp. 11911-11920, January 2021.

[8] M. Elsisi, "Design of Neural Network Predictive Controller Based on Imperialist Competitive Algorithm for Automatic Voltage Regulator,” Neural Computing and Applications, vol. 31, pp. 5017-5027, January 2019.

[9] A. Bourchy, L. Barnes, L. Bessette, F. Chalencon, A. Joron, and J. M. Torrenti, "Optimization of Concrete Mix Design to Account for Strength and Hydration Heat in Massive Concrete Structures," Cement and Concrete Composites, vol. 103, pp. 233-241, October 2019.

[10] S. Minhaj, S. Kazmi, M. J. Munir, Y. F. Wu, I. Patnaikuni, Y. Zhou, et al., "Axial Stress-Strain Behavior of Macro-Synthetic Fiber Reinforced Recycled Aggregate Concrete," Cement and Concrete Composites, vol. 97, pp. 341-356, March 2019.

[11] B. A. Young, A. Hall, L. Pilon, P. Gupta, and G. Sant, "Can the Compressive Strength of Concrete be Estimated from Knowledge of the Mixture Proportions? New Insights from Statistical Analysis and Machine Learning Methods," Cement and Concrete Research, vol. 115, pp. 379-388, January 2019.

[12] O. M. Olofinnade, A. N. Ede, and J. M. Ndambuki, "Experimental Investigation on the Effect of Elevated Temperature on Compressive Strength of Concrete Containing Waste Glass Powder,” International Journal of Engineering and Technology Innovation, vol. 7, no. 4, pp. 280-291, September 2017.

[13] D. S. Morales, J. D. Ríos, A. M. D. L. Concha, H. Cifuentes, J. R. Jiménez, and J. M. Fernández, "Effect of Moderate Temperatures on Compressive Strength of Ultra-High-Performance Concrete: A Microstructural Analysis," Cement and Concrete Research, vol. 140, 106303, February 2021.

[14] M. A. Villalobos Granadino and M. M. E. Lozada Silva, “Análisis y Diseño para la Construcción de la Vía de Evitamiento de la Ciudad de Jaén Región Cajamarca 2015,” Tesis Pregrado, Facultad de Ingeniería, Universidad Católica Santo Toribio de Mogrovejo, Chiclayo, 2017.

[15] A. A. Quiróz Vásquez, "Evaluación de los Defectos en la Construcción de Viviendas Informales de Albañilería en el Sector Fila Alta, Provincia Jaén-Cajamarca,” Tesis Pregrado, Facultad de Ingeniería Civil, Universidad Nacional de Cajamarca, Cajamarca, 2014.

[16] J. S. F. Correa and O. T. Gonzales, "Resistencia a Compresión del Concreto Utilizado en Losas Aligeradas de las Construcciones Informales en la Ciudad de Jaén,” Tesis Pregrado, Facultad de Ingeniería Civil, Universidad Nacional de Jaén, Cajamarca, 2019.

[17] R. L. G. Pinedo, "Evaluación de la Vulnerabilidad Sísmica de las Edificaciones en el Sector los Aromos, Jaén,” Tesis Pregrado, Facultad de Ingeniería Civil, Universidad Nacional de Cajamarca, Cajamarca, 2017.

[18] U. Nath and P. Barua, "Optimisation of Concrete Mixture Proportioning Using Taguchi's Method," Indian Concrete Journal, vol. 78, no. 9, pp. 52-56, September 2004.

[19] J. Lizarazo and J. Gómez, "Desarrollo de un Modelo de Redes Neuronales Artificiales para Predecir la Resistencia a la Compresión y la Resistividad Eléctrica del Concreto,” Ingeniería e Investigación, vol. 27, no. 1, pp. 11-18, January 2007. 
[20] L. González, A. Guerrero, S. Delvasto, and A. Will, "Estimación del Índice de Tenacidad Flexural $\mathrm{I}_{5}$ en Concretos Fibro-Reforzados, Usando Redes Neuronales Artificiales,” Revista Colombiana de Materiales, vol. 5, no. 5, pp. 24-29, May 2014.

[21] A. El-Shahat, Advanced Applications for Artificial Neural Networks, Croatia: IntechOpen, 2018.

[22] J. L. G. Rosa, Biologically Plausible Artificial Neural Networks, Croatia: IntechOpen, 2013.

[23] L. Acuña, P. Espinoza, I. Moromi, A. Torre, and F. García, "Concreto de Alto Rendimiento, Predicción de Su Resistencia a la Compresión Mediante Redes Neuronales Artificiales,” Tecnia, vol. 27, no. 1, pp. 51-59, June 2017.

[24] L. Octavio, A. P. Guerrero, S. Delvasto, and A. Ernesto, "Redes Neuronales Artificiales para Estimar Propiedades en Estado Fresco y Endurecido, para Hormigones Reforzados con Fibras Metálicas," Cuaderno Activa, vol. 9, no. 9, pp. 95-107, January 2017.

[25] Standard Practice for Selecting Proportions for Normal, Heavyweight, and Mass Concrete, ACI 211.1-91, 2002.

[26] Práctica Normalizada para la Elaboración y Curado de Especímenes de Concreto en Campo, NTP 399.033, 2015.

[27] Standard Test Method for Compressive Strength of Cylindrical concrete Specimens, ASTM C 39/C 39M, 2017.

[28] Método de Ensayo Normalizado para la Determinación de la Resistencia a la Compresión del Concreto en Muestras Cilíndricas, NTP 339.034, 2015.

[29] Standard Practice for Making and Curing Concrete Test Specimens in the Laboratory, ASTM C 192/C 192M, 2017.

[30] L. O. Gonzáles, A. P. G. Zuñiga, S. D. Arjona, and A. L. E. Will, "Red Neuronal Artificial para Estimar la Resistencia a Compresión, en Concretos Fibro-Reforzados con Polipropileno," Ventana Informática, no. 26, pp. 11-18, November 2012.

[31] S. Goyal and G. K. Goyal, "Cascade and Feedforward Backpropagation Artificial Neural Network Models for Prediction of Sensory Quality of Instant Coffee Flavoured Sterilized Drink," Canadian Journal on Artificial Intelligence, Machine Learning, and Pattern Recognizing, vol. 2, no. 6, pp. 78-82, August 2011.

[32] M. H. D. Tello, "Uso de las Redes Neuronales Artificiales en el Modelado del Ensayo de Resistencia a Compresión de Concreto de Construcción Según la Norma ASTM C 39/C 39M,” Tesis Pregrado, Facultad de Ingeniería Civil, Universidad Nacional de Cajamarca, Cajamarca, 2017.

[33] L. O. G. Salcedo, A. P. G. Zuñiga, S. D. Arjona, and A. L. E. Will, "Redes Neuronales Artificiales para Estimar Propiedades en Estado Fresco y Endurecido, para Hormigones Reforzados con Fibras Metálicas,” Cuaderno Activa, vol. 9 , no. 9, pp. 95-107, December 2017.

[34] M. Elsisi, "Future Search Algorithm for Optimization," Evolutionary Intelligence, vol. 12, no. 1, pp. 21-31, September 2018.

Copyright $(\subset$ by the authors. Licensee TAETI, Taiwan. This article is an open access article distributed under the terms and conditions of the Creative Commons Attribution (CC BY-NC) license (https://creativecommons.org/licenses/by-nc/4.0/). 